\title{
Absence of gender differences in memory for map learning
}

\author{
WILLIAM W. BEATTY and JANET A. BRUELLMAN \\ North Dakota State University, Fargo, North Dakota
}

\begin{abstract}
To test the possibility that gender differences in the accuracy of geographical knowledge might be related to long-term retention of map learning, undergraduate men and women first learned the locations of 15 "towns" on an unfamiliar map. After a 45-min delay filled with a test of geographical knowledge and other visuospatial tasks, retention was measured. For some subjects, retention was measured a second time after a 48-h delay. In agreement with earlier findings, men displayed more accurate knowledge of the locations of real places (i.e., geographical knowledge), but there was no gender difference in acquisition or retention of the location of places on the unfamiliar map.
\end{abstract}

In an earlier study (Beatty \& Tröster, 1987), we found that male undergraduates outperformed female undergraduates on a variety of measures of geographical knowledge, but that there was no gender difference in the acquisition of information about the location of places on an unfamiliar map when performance was tested immediately after each study trial. This latter finding suggested that the gender differences in geographical knowledge could not be attributed to differences in the capacity to acquire knowledge about place location, but the possibility remained that females might forget such information more rapidly than males. The present study evaluated that possibility.

\section{METHOD}

\section{Subjects}

Male and female undergraduates from North Dakota State University participated in the study as part of a class project in their experimental psychology course or to obtain extra credit in introductory-level psychology classes. Mean demographic characteristics of the sample are summarized in Table 1.

\section{Procedure}

Subjects were first tested on the New Map Test using the same materials and procedures described by Beatty and Tröster (1987, Experiment 3 ). In brief, they were told to learn the locations of 15 hypothetical towns that were located on a map of three contiguous "states." A trial consisted of a 60-sec study period followed by immediate recall. Four study-recall trials were given. After the last recall test, subjects were told to try to remember the locations of each of the towns.

Next, the subjects completed the revised version of the Fargo Map Test (FMT-R, Beatty, in press), an objective test of geographical knowledge. The FMT-R requires subjects to locate 10 gross features of U.S. geography (e.g., the Atlantic Ocean) and 30 U.S. cities on an outline map of the U.S. and 18 cities on an outline map of the North Dakota-South Dakota-Minnesota region. In addition, subjects indicated in which state each of the 30 U.S. cities was located (termed CITYSTATE), and which of the U.S. states and tristate cities they had visited sometime during their lives.

Address correspondence to the first author at: Department of Psychology, North Dakota State University, Fargo, ND 58105.
For the remainder of the 45-min retention interval, subjects completed a version of Piaget and Inhelder's (1956) water level problem and the Everyday Spatial Activities Test (Lunneborg \& Lunneborg, 1986). Gender differences have been reported on both tasks (Liben, 1974; Lunneborg \& Lunneborg, 1986; Thomas, Jamison, \& Hammel, 1973) and were replicated $(p<.001)$ in the present sample.

Finally, all subjects were given a delayed retention test of the location of towns on the New Map Test. A subgroup (12 males, 25 females) received a second delayed retention test $48 \mathrm{~h}$ later.

\section{RESULTS AND DISCUSSION}

As shown in Table 1, males and females acquired knowledge of the location of places on the unfamiliar map at similar rates and remembered this information over the delay intervals to about the same extent. Forgetting by both sexes was negligible over $45 \mathrm{~min}$ and modest over $48 \mathrm{~h}$. Even after a 48-h delay, both males and females accurately located many more places on the New Map Test than immediately after the first study trial $(p<.001)$.

In contrast, reliable gender differences in geographical knowledge, as measured by the FMT-R, were observed. In agreement with previous studies (Beatty, in press; Beatty \& Tröster, 1987), males performed more accurately than did females in locating gross features of U.S. geography, U.S. cities, and cities in the tristate region. Beatty and Tröster (1987) found a gender difference in naming the state in which U.S. cities are located (CITYSTATE), a nonspatial measure of geographical knowledge, but this observation was not replicated in the present study.

The highly similar performance by males and females in acquiring and remembering place locations on an unfamiliar map confirms and extends our earlier observations (Beatty \& Tröster, 1987). The present finding that females and males retain knowledge of place locations equally well makes it most unlikely that gender differences in geographical knowledge arise from differences in the capacity for map learning or memory. Since some 
Table 1

Mean Demographic Characteristics and Performance on the New Map Test and the Fargo Map Test (Revised)

\begin{tabular}{lccc}
\hline & Males & Females & F Ratio for Gender \\
\hline & Demographic & & \\
$N$ & 59 & 64 & \\
Age (Years) & 21.5 & 22.2 & 0.84 \\
Years Education & 13.4 & 13.6 & 0.60 \\
Years Lived in U.S. & 21.4 & 22.1 & 0.79 \\
Years Lived in ND, SD, or MN & 19.1 & 18.7 & 0.13 \\
No. U.S. States Visited & 17.0 & 16.8 & 0.00 \\
No. Tristate Cities Visited & 10.5 & 10.0 & 0.64 \\
& & & \\
Trial 1 & New Map Test* & & \\
Trial 2 & 45 & 48 & 0.82 \\
Trial 3 & 65 & 65 & 0.00 \\
Trial 4 & 77 & 79 & 0.15 \\
45-min Delay & 83 & 87 & 1.44 \\
48-h Delay & 79 & 85 & 2.37 \\
& 73 & 73 & 0.01
\end{tabular}

Fargo Map Test (Revised)*

\begin{tabular}{lccc} 
Gross Features of U.S. & 96 & 90 & $4.56 \dagger$ \\
Location of U.S. Cities & 54 & 42 & $12.64 \ddagger$ \\
CITYSTATE & 93 & 92 & 0.02 \\
Location of Tristate Cities & 69 & 54 & $16.54 \ddagger$ \\
\hline *Performance on the tests is given as percentage of correct responses. $\quad \dagger p<.05 . \quad \neq p<.001$.
\end{tabular}

evidence suggests that men pay more attention to maps than do women (Beatty \& Tröster, 1987), this difference may account for gender differences in geographical knowledge.

\section{REFERENCES}

Beatty, W. W. (in press). The Fargo Map Test: A standardized method of assessing remote memory for visuospatial information. Journal of Clinical Psychology.

BeAtTy, W. W., \& Tröster, A. I. (1987). Gender differences in geographical knowledge. Sex Roles, 16, 565-590.
LiBEN, L. S. (1974). Operative understanding of horizontality and its relation to longterm memory. Child Development, 45, 416-424.

LunNeborg, P. W., \& LunNeborG, C. E. (1986). Everyday Spatial Activities Test for studying differential spatial experience and vocational behavior. Journal of Vocational Behavior, 28, 135-141.

Piaget, J., \& INHELDER, B. (1956). The child's conception of space. New York: Humanities Press.

Thomas, H., Jamison, W., \& Hammel, D. D. (1973). Observation is insufficient for discovering that the surface of still water is invariantly horizontal. Science, 181, 173-174.

(Manuscript received for publication February 16, 1987.) 